\title{
Pengaruh Rasio Kas, Working Capital TurnOver, Solvabilitas, Tingkat Suku Bunga terhadap Profitabilitas
}

(Studi Empiris pada Aneka Industri yang Terdaftar di Bursa Efek Indonesia Periode 2012-2016)

\section{Siti Tiffanny Guci, S.E}

Universitas Prima Indonesia

STG_sitigucitiffany@yahoo.com

\author{
Siska Krisjayanti \\ Universitas Prima Indonesia \\ skrisjayanti20@gmail.com
}

\section{Erick}

Universitas Prima Indonesia

erickyangck@gmail.com

ABSTRACT The purpose of this study was to test and diagnose the effect of cash ratios, working capital turnover, solvency, interest rates on profitability (Emprising studies on various industries listed on the Indonesia Stock Exchange. The theory used in this study was the theories of Cash Ratio, Working Capital Turnover, Solvency, Interest Rate. The research method used is descriptive quantitative, this research is causal / clausal. In this study, data collection was carried out through documentation studies. The study used types and secondary data sources. The results of this study were the Cash Ratio, Working Capital Turnover, Solvency, Interest Rate, simultaneously have a not positive and significant effect on the firm value of empirical studies on Various Industries listed on the Stock Exchange for the period 2013-2016. The conclusions in this study are Cash Ratio, Working Capital Turnover, Solvency and Interest Rates are partially taxed not positive and significant spirit towards the value of empirical studies on Various Industries listed on the IDX for the period 2013-2016

Keywords Cash Ratio, Working Capital Turnover, Solvency, dan Interest Rate

\section{PENDAHULUAN}

\subsection{Latar Belakang}

Sub sektor otomotif dan komponen, sub sektor tekstil dan garmen, yang pertumbuhannya terbilang sangat kencang, merupakan sektor aneka industri yang tercantum di Bursa Efek Indonesia. Cara perusahaan dalam mengolah sumber daya yang dimilikinya untuk hasil laba pada tingkat penjualan, aset, dan modal saham tertentu disebut juga Profitabilitas. Selain itu, naik turunnya tingkat daya laba perusahaan dapat memprediksi seberapa besar laba yang akan diterima perusahaan di masa yang akan datang. Tingkat Pengembalian Aset adalah salah satu cara dari rasio profitabilitas yang 
dimaksudkan untuk menakar efektivitas perusahaan di dalam menghasilkan keuntungan dengan memanfaatkan aktiva yang dimilikinya.

Kebanyakan perusahaan memiliki kas yang digunakan untuk membayar hutang lancar maupun membiayai biaya operasionalnya.Perusahaan yang memiliki kas yang tinggi tentu profitabilitasnya menurun disebabkan perusahaan memanfaatkan kas ini untuk melunasi hutang jangka pendek yang telah jatuh waktu tenggatnya.

Beberapa dana yang ditemukan di dalam aktiva lancar yang digunakan oleh setiap perusahaan untuk memodali kegiatan operasinya sehari-hari, dimana modal kerja yang telah disingkirkan itu diharapkan bisa masuk lagi kedalam perusahaan dalam waktu yang pendek disebut Modal Kerja. Modal kerja dapat dinilai dari perubahan modal kerja (working capital turnover), perputaran piutang (receivable turnover), perubahan inventori (inventory turnover). Meningkatnya tingkat perputaran modal berarti peluang bertambahnya laba juga semakin besar.Laba yang tinggi mempengaruhi nilai profitabilitas perusahaan tersebut.Lamanya periode perputaran modal kerja adalah bergantung kepada waktu periode perubahan dari masing-masing unsur dari modal kerja tersebut.

Semakin besar hutang pada struktur modal suatu perusahaan, semakin tinggi pula beban tetap dan komitmen pembayaran kembali yang diakibatkan. Jika perusahaan memakai lebih banyak hutang dibandingkan dengan modal sendiri, maka solvabilitas akan semakin besar karena beban bunga yang harus ditanggung juga akan bertambah tinggi, dan hal ini akan mengakibatkan profitabilitas suatu perusahaan mengalami penurunan.

Perusahaan dalam melakukan penyimpanan uang ke bank akan mendapatkan bunga bank. Faktor internal dan eksternal bank dapat mempengaruhi perkembangan tingkat suku bunga yang ditetapkan oleh bank. Struktur aktiva produktif bank yang sebagian returnnya sangat dipengaruhi oleh fluktuasi suku bunga SBI semua termasuk dalam faktor internal, sedangkan faktor eksternal berpengaruh pada jumlah nasabah yang mengharapkan penurunan tingkat suku bunga sebelum mengajukan pinjaman kepada bank. Pendekatan neraca dengan melihat secara utuh sebagai satu kesatuan merupakan salah satu pendekatan dalam menganalisis manajemen keuangan.

\section{Landasan Teori}

\subsection{Pengertian Rasio Kas}

Menurut Kasmir (2012:138-139) alat yang digunakan untuk menakar seberapa besar uang kas yang tersedia untuk membayar hutang disebut juga rasio kas. Kita bisa mengecek ketersediaan uang kas dengan cara melihat tersedianya dana kas seperti rekening giro atau tabungan di bank. Dapat dikatakan rasio ini merupakan alat untuk mengukur kemampuan perusahaan untuk membayar hutang - hutang jangka pendeknya.

Menurut Kasmir (2012:139) rumus cash ratio :

$$
\text { Cash ratio }=\frac{\text { Kas }+ \text { Bank }}{\text { Current Liabilities }}
$$

\subsection{Pengertian Working Capital Turnover}


Menurut Kasmir (2014:182) salah satu rasio untuk menakar atau menilai keefektifan modal kerja perusahaan selama periode tertentu disebut juga perputaran modal kerja. Artinya seberapa banyak modal kerja berputar selama suatu periode atau dalam suatu periode.

$$
\text { Perputaran Modal Kerja }=\frac{\text { Penjualan }}{\text { Modal Kerja Bersih }}
$$

\subsection{Pengertian Solvabilitas}

Menurut Kasmir (2012:151) rasio yang digunakan untuk menakar sejauh mana aktiva perusahaan dimodali dengan utang dimaksud dengan rasio solvabilitas atau leverage ratio. Artinya berapa besar beban utang yang ditanggung perusahaan dibandingkan dengan aktivanya. Dalam arti luas dikatakan bahwa rasio solvabilitas dipakai untuk menakar kemampuan perusahaan untuk memenuhi seluruh kewajibannya, apabila perusahaan ditutup (dilikuidasi) baik jangka pendek maupun jangka panjang.

Menurut Kamaludin dan Indriani (2012:42) rasio solvabilitas merupakan rasio disediakan pemilik untuk membandingkan dengan finansial yang diberikan oleh kreditor.

Menurut Harahap (2013:303), Rasio solvabilitas menunjukan kemampuan perusahaan dalam membayar kewajiban jangka panjang perusahaan tersebut apabila perusahaan mengalami penutupan. Rasio ini bisa dihitung dari pos-pos yang sifatnya jangka panjang seperti aktiva tetap dan utang jangka panjang.

Berdasarkan pendapat di atas dapat disimpulkan bahwa solvabilitas adalah suatu rasio yang menilai kemampuan perusahaan menggunakan total hutang untuk membiayai aktiva ataupun ekuitas. Hutang yang dimaksudkan di atas adalah hutang jangka pendek maupun hutang jangka panjang.

$$
\text { Debt to asset ratio }=\frac{\text { Total Debt }}{\text { Total assets }}
$$

\subsection{Pengertian Tingkat Suku Bunga}

Menurut Gumanti (2011:254) suku bunga adalah harga dari uang (the price of money). Bila menganggap uang sebagai suatu komoditas seperti halnya barang-barang yang lain, suku bunga ditetapkan oleh besar kecilnya permintaan dan penawaran atas uang tersebut. Suku bunga bervariasi dapat diakibatkan perubahan dalam penawaran dan permintaan uang.

\section{Indikator suku bunga adalah bi.rate}

\subsection{Pengertian Profitabilitas}

Menurut Wahyudiono (2014:81) untuk mengukur efisiensi penggunaan kativa perusahaan dapat menggunakan rasio ini. Selain itu, penjualan yang berhasil diciptakan 
dapat menggunakan untuk mengait efisiensi kativa perusahaan. Keuntungan yang diambil perusahaan relatif cukup tinggi dan ada pula relatif cukup rendah.

$$
\mathrm{ROA}=\frac{\text { Net Income }}{\text { Total Asset }}
$$

\subsection{Teori Pengaruh Rasio Kas Terhadap Profitabilitas}

Menurut Sitanggang (2012 : 36) Semakin rendah profitabilitasnya maka semakin tinggi juga tingkat likuiditas, dan sebaliknya. Cerminan bahwa ada resiko yang dipertaruhkan dalam hal kebijakan agresif yang menetapkan jumlah harta lancar yang relatif lebih kecil terhadap penjualan berakibat pada penjualan yang lebih kecil karena jumlah persediaan sangat ketat

\subsection{Teori Pengaruh Working Capital Turnover Terhadap Profitabilitas}

Menurut Hery (2016 : 96) perusahaan sedang memiliki kelebihan modal kerja berarti memiliki perputaran modal kerja yang rendah. Tingginya perputaran persediaan barang dagang dapat menyebabkan perputaran modal kerja yang tinggi atau sebaliknya. rendahnya perputaran persediaan barang dagang atau piutang usaha atau bisa juga karena terlalu besarnya saldo kas.

\subsection{Teori Pengaruh Solvabilitas Terhadap Profitabilitas}

Menurut Sunyoto (2013:129) Solvabilitas yang berpengaruh positif pada tingkat kinerja keuangan perusahaan, karena jika suatu perusahaan mampu memenuhi kewajiban finansialnya pada saat perusahaan tersebut dilikuidasi dapat dikatakan kondisi tingkat kinerja keuangan tersebut dalam keadaan sehat.

\subsection{Teori Pengaruh Tingkat Suku Bunga Terhadap Profitabilitas}

Menurut Kasmir (2014 : 158) kredit yang akan dibebankan kepada debitur, dapat menentukan besar kecilnya suku bunga. Komponen - komponen ada yang dapat diperkecil pula yang tidak. Komponen - komponen ini kemudian dijumlahkan sehingga menjadi dasar penentuan bunga kredit yang diberikan kepada nasabah.

\section{METODE PENELITIAN}

\subsection{Tempat dan Waktu Penelitian}

Penelitian ini dilakukan pada Perusahaan Aneka Industri yang ada di BEI (Bursa Efek Indonesia) melalui media internet yaitu www.idx.co.id. Penelitian ini direncanakan sejak bulan Agustus 2018 sampai dengan Januari 2019.

\subsection{Jenis Penelitian}

Penelitian deskriptif kuantitatif merupakan jenis penelitian yang digunakan. Menurut Sanusi (2012:13) desain penelitian yang disusun dalam rangka memberikan gambaran secara sistematis tentang informasi ilmiah yang berasal dari subjek atau objek penelitian disebut juga desain penelitian deskriptif. Penelitian deskriptif berfokus pada penjelasan sistematis tentang fakta yang diperoleh saat penelitian dilakukan. 


\subsection{Uji Asumsi Klasik}

Uji normalitas, uji multikolineritas, uji heterokedastisitas, dan uji autokorelasi merupakan uji-uji yang dilakukan di pengujian asumsi klasik. Hasil pengujian asumsi klasik ini menggunakan software SPSS 21.0.

\subsubsection{Uji Normalitas}

Menurut Ghozali (2016 :154) menguji apakah dalam model regresi, variabel pengganggu atau residual memiliki nilai signifikat distribusi normal merupakan tujuan dari Uji Normalitas.

\subsubsection{Uji Multikolinieritas}

Menurut Ghozali (2016:103) menguji apakah model regresi ditemukan adanya korelasi antar variabel bebas (independen) merupakan tujuan dari Uji Multikolinieritas. Model regresi yang baik harusnya tidak terjadi korelasi di antara variabel independen.

\subsubsection{Uji Autokorelasi}

Menurut (Ghozali 2016:107) menguji apakah dalam model regresi linear ada korelasi antara kesalahan penggangu pada periode $t$ dengan kesalahan pengganggu pada periode t-1 (sebelumnya) merupakan tujuan dari Uji Autokorelasi. Jika terjadi korelasi, maka dinamakan ada masalah autokorelasi.

\subsubsection{Uji Heteroskedastisitas}

Menurut Ghozali (2016:134), menguji apakah dalam model regresi terjadi ketidaksamaan variance dari residual satu pengamatan ke pengamatan yang lain merupakan tujuan dari Uji Heteroskedastisitas. Model regresi yang baik yaitu yang Homokedastisitas atau tidak terjadi heterokedastisitas.

\subsection{Model Penelitian}

Analisis regresi linier berganda merupakan model penelitian yang digunakan. Dimana analisa linier berganda dipakai untuk mengetahui besarnya pengaruh variabel bebas terhadap variabel terikat.

\subsubsection{Uji Koefisien Determinasi (R2)}

Menurut Ghozali (2016:95), pada intinya untuk mengukur seberapa jauh kemampuan model dalam menerangkan beberapa variabel dependen dapat mengunakan Uji Koefisien Determinasi $\left(\mathrm{R}^{2}\right)$.

\subsubsection{Pengertian Pengujian Hipotesis Secara Simultan (Uji F)}

Menurut Ghozali (2016:96), semua variabel independen atau bebas yang dimasukkan dalam model mempunyai pengaruh secara positif atau negatif bersamasama terhadap variabel dependen atau terikat pada dasarnya dapat ditunjukan dengan Uji Statistik F. 


\subsubsection{Pengertian Pengujian Hipotesis secara Parsial (Uji t)}

Menurut Ghozali (2016:97-98), "Uji statistik t pada dasarnya memperlihatkan seberapa jauh pengaruh satu variabel penjelas atau independen secara individual dalam menerangkan variasi variabel dependen".

\section{IV.1 Hasil Penelitian}

\subsubsection{Statistik Deskriptif}

Tabel IV.1 : Deskriptif Statistik Penelitian

\begin{tabular}{|c|r|r|r|r|r|}
\hline Descriptive Statistics & $\mathrm{N}$ & Minimum & Maximum & Mean & Std. Deviation \\
\hline CR & 44 &, 01 & 1,14 &, 1975 &, 25671 \\
\hline PMK & 44 & $-1,61$ & 35,04 & 7,3964 & 8,71551 \\
\hline DAR & 44 &, 17 &, 70 &, 4495 &, 15227 \\
\hline BIRATE & 44 & 4,75 & 7,75 & 6,8750 & 1,24534 \\
\hline ROA & 44 &, 00 &, 24 &, 0475 &, 06187 \\
\hline Valid N (listwise) & 44 & & & & \\
\hline
\end{tabular}

Berdasarkan tabel IV.1 tersebut menunjukkan nilai terkecil, nilai terbesar, nilai rata-rata (mean), dan standar deviasi dari variabel rasio kas, working capital turnover, solvabilitas, tingkat suku bunga dan profitabilitas dengan rincian sebagai berikut:

1. Variabel rasio kas memiliki jumlah sampel sebanyak 44, dengan nilai minimum 0,01 pada PT. Nipress, Tbk tahun 2013 dan nilai maksimum 1,14 pada PT. Indospring,Tbk tahun 2013 sedangkan nilai mean 0,1975 dengan standar deviasi 0,25671 .

2. Variabel working capital turnover memiliki jumlah sampel sebanyak 44, dengan nilai minimum -1,61 pada PT. Nusantara Inti Corpora,Tbk tahun 2016 dan nilai maksimum 35,04 pada Pt. Nipress tahun 2013 sedangkan nilai mean 7,3964 dengan standar deviasi 8,71551 .

3. Variabel solvabilitas memiliki jumlah sampel sebanyak 44, dengan nilai minimum 0,17 pada Pt. Indospring tahun 2016 dan nilai maksimum 0,70 pada Pt. Nipress tahun 2013 sedangkan nilai mean 0,4495 dengan standar deviasi 0,15227 .

4. Variabel tingkat suku bunga memiliki jumlah sampel sebanyak 44, dengan nilai minimum 4,75 pada PT. Astra Internasional,Tbk tahun 2016 dan nilai maksimum 7,75 pada Pt. Astra Internasional tahun 2014 sedangkan nilai mean 6,8750 dengan standar deviasi 1,24534.

5. Variabel profitabilitas memiliki jumlah sampel sebanyak 44, dengan nilai minimum 0,00 pada PT. Indorama Syntetics,Tbk tahun 2013dan nilai maksimum 0,24 pada Pt. Selamat Sempurna tahun 2014 sedangkan nilai mean 0,0475 dengan standar deviasi 0,06187 .

\subsection{Hasil Uji Asumsi Klasik}

4.2.1.Uji Normalitas

a. Sebelum Transformasi 
Tabel 4.2 : One-Sample Kolmogorov-Smirnov Test

Sebelum Transformasi

\begin{tabular}{|c|c|c|}
\hline \multicolumn{3}{|c|}{ One-Sample Kolmogorov-Smirnov Test } \\
\hline \multirow{2}{*}{\multicolumn{2}{|c|}{$\mathrm{N}$}} & Unstandardized Residual \\
\hline & & 44 \\
\hline \multirow{2}{*}{$\begin{array}{c}\text { Normal } \\
\text { Parameters } \mathrm{a}, \mathrm{b}\end{array}$} & Mean &, 0000000 \\
\hline & Std. Deviation &, 05866338 \\
\hline \multirow{3}{*}{$\begin{array}{c}\text { Most Extreme } \\
\text { Differences }\end{array}$} & Absolute &, 221 \\
\hline & Positive & ,221 \\
\hline & Negative &,- 157 \\
\hline \multicolumn{2}{|c|}{ Test Statistic } & ,221 \\
\hline \multicolumn{2}{|c|}{ Asymp. Sig. (2-tailed) } &, $000^{c}$ \\
\hline \multicolumn{3}{|c|}{ a. Test distribution is Normal. } \\
\hline \multicolumn{3}{|c|}{ b. Calculated from data. } \\
\hline \multicolumn{3}{|c|}{ c. Lilliefors Significance Correction. } \\
\hline
\end{tabular}

Dari tabel 4.2 uji normalitas dengan menggunakan statistik KolmogorovSmirnov di atas, dapat diketahui bahwa variabel rasio kas, working capital turnover, solvabilitas, tingkat suku bunga dan profitabilitasbelum memenuhi syarat distribusi normal karena nilai sig $0,000<0,05$ sehingga data tersebut tidak normal.Untuk mengubah nilai residual agar berdistribusi normal, maka dilakukan transformasi data ke logaritma natural (Ln) dengan menggunakan SPSS.Caranya adalah dengan melakukan logaritma natural terhadap semua variabel yang tidak berdistribusi normal. Setelah transformasi data dilakukan maka hasil uji normalitas data dari penelitian ini dapat dilihat sebagai berikut :

b. Sesudah Transformasi

Tabel 4.3 : One-Sample Kolmogorov-SmirnovTest SesudahTransformasi

\begin{tabular}{|c|c|c|}
\hline \multicolumn{3}{|c|}{ One-Sample Kolmogorov-Smirnov Test } \\
\hline & & Unstandardized Residual \\
\hline \multicolumn{2}{|c|}{$\mathrm{N}$} & 32 \\
\hline \multirow{2}{*}{$\begin{array}{c}\text { Normal } \\
\text { Parameters }\end{array}$} & Mean &, 0000000 \\
\hline & Std. Deviation & ,86178031 \\
\hline \multirow{3}{*}{$\begin{array}{l}\text { Most Extreme } \\
\text { Differences }\end{array}$} & Absolute &, 081 \\
\hline & Positive & ,081 \\
\hline & Negative &,- 073 \\
\hline \multicolumn{2}{|c|}{ Test Statistic } &, 081 \\
\hline \multicolumn{2}{|c|}{ Asymp. Sig. (2-tailed) } & $200^{\mathrm{c}, \mathrm{d}}$ \\
\hline \multicolumn{3}{|c|}{ a. Test distribution is Normal. } \\
\hline \multicolumn{3}{|c|}{ b. Calculated from data. } \\
\hline \multicolumn{3}{|c|}{ c. Lilliefors Significance Correction. } \\
\hline \multicolumn{3}{|c|}{$\mathrm{d}$. This is a lower bound of the true significance. } \\
\hline
\end{tabular}

Dari tabel IV.3 uji normalitas dengan memakai statistik Kolmogorov-Smirnov di 
atas, diketahui bahwa variabel rasio kas, working capital turnover, solvabilitas, tingkat suku bunga dan profitabilitas sudah memenuhi syarat distribusi normal karena nilai signifikan $0,200>0,05$ sehingga data tersebut normal. Analisis histogram dapat disajikan tampilannya sebagai berikut:

a. Sebelum Transformasi

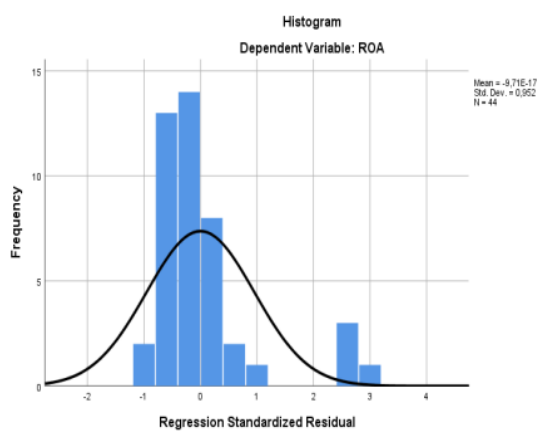

\section{Gambar 4.1 : Grafik Histogram Sebelum Transformasi}

Dari histogram tersebut, dapat disimpulkan data residual berdistribusi tidak normal karena dapat dilihat dari arah histogram yang miring ke kanan maupun ke kiri dan tidak membentuk lonceng terbalik.Untuk mengubah nilai residual agar berdistribusi normal, maka dilakukan transformasi data ke logaritma natural (Ln) dengan menggunakan SPSS.Caranya adalah dengan melakukan logaritma natural terhadap semua variabel yang tidak berdistribusi normal. Setelah transformasi data dilakukan maka hasil uji normalitas data dari penelitian ini dapat dilihat sebagai berikut :

b. Sesudah Transformasi

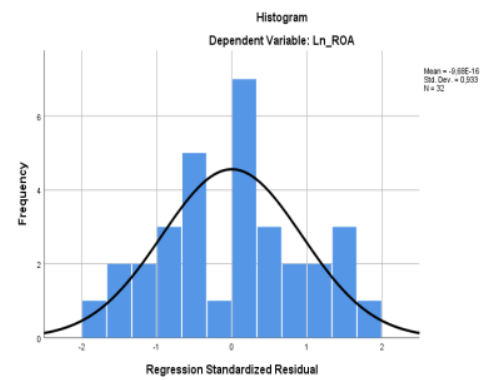

Gambar 4.2 : Grafik Histogram Sesudah Transformasi

Dari histogram tersebut, dapat disimpulkan data residual berdistribusi normal karena dilihat dari arah histogram yang tidak miring ke kanan maupun ke kiri dan membentuk lonceng terbalik.

Demikian pula dengan hasil normal probability plot berikut ini: a. Sebelum Transformasi 


\section{Gambar 4.3 : Normal Probability Plot Sebelum Transformasi}

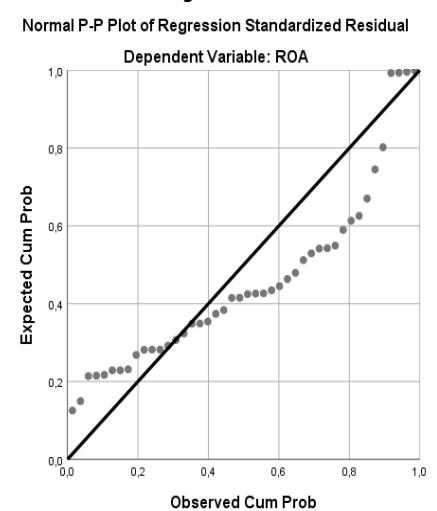

Dari hasil normal probability plot terlihat titik-titik tidak menyebar disekitar garis diagonal, dan mengikuti arah garis diagonal sehingga data berdistribusi tidak normal. Untuk mengubah nilai residual agar berdistribusi normal, maka dilakukan transformasi data ke logaritma natural (Ln) dengan menggunakan SPSS.Caranya adalah dengan melakukan logaritma natural terhadap semua variabel yang tidak berdistribusi normal. Setelah transformasi data dilakukan maka hasil uji normalitas data dari penelitian ini dapat dilihat sebagai berikut :

\section{b. Sesudah Transformasi}

Gambar 4.4 : Normal Probability Plot Sesudah Transformasi

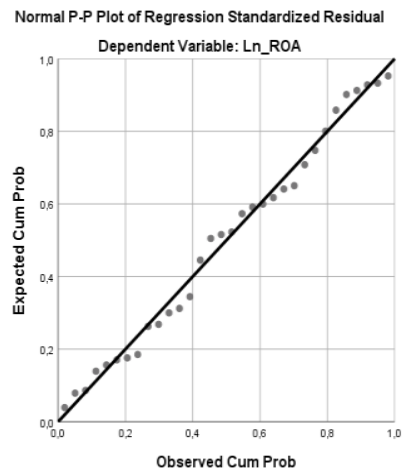

Dari hasil normal probability plot terlihat titik-titik mendekat di sekitar garis diagonal, dan mengikuti arah garis diagonal sehingga data berdistribusi normal. Hasil dari uji normalitas dengan menggunakan statistic Kolmogorov Smirnov Test:

\subsubsection{Uji Multikolinieritas}

a. Sebelum Transformasi

Tabel 4.5 : Hasil Uji Multikolinieritas Sebelum Transformasi

\begin{tabular}{|c|c|c|c|}
\hline \multirow{2}{*}{\multicolumn{2}{|c|}{ Model }} & \multicolumn{2}{|c|}{ Collinearity Statistics } \\
\hline & & Tolerance & VIF \\
\hline \multirow[t]{5}{*}{1} & (Constant) & & \\
\hline & $\mathrm{CR}$ & 934 & 1,071 \\
\hline & PMK & ,732 & 1,366 \\
\hline & DAR & ,720 & 1,389 \\
\hline & BIRATE & ,984 & 1,016 \\
\hline
\end{tabular}


Tabel 4.5 diatas menunjukkan nilai tolerance variabel rasio kas, working capital turnover, solvabilitas, tingkat suku bunga lebih besar dari 0,10 dapat disimpulkan bahwa tidak terjadi multikolinearitas. Nilai VIF yang diperoleh untuk variabel rasio kas, working capital turnover, solvabilitas, tingkat suku bunga lebih kecil 10.Jadi dapat disimpulkan bahwa tidak terjadi multikolinearitas antar variabel independen dalam model regresi tersebut.

b. Sesudah Transformasi

Tabel 4.6 : Hasil Uji Multikolinieritas Sesudah Transformasi

\begin{tabular}{|c|c|c|c|}
\hline \multirow{2}{*}{\multicolumn{2}{|c|}{ Model }} & \multicolumn{2}{|c|}{ Collinearity Statistics } \\
\hline & & Tolerance & VIF \\
\hline \multirow[t]{5}{*}{1} & (Constant) & & \\
\hline & Ln_CR & ,509 & 1,966 \\
\hline & Ln_PMK & ,565 & 1,770 \\
\hline & Ln_DAR & ,664 & 1,506 \\
\hline & Ln_BIRATE & ,943 & 1,061 \\
\hline
\end{tabular}

Berdasarkan tabel 4.6 diatas menunjukkan nilai tolerance variabel rasio kas, working capital turnover, solvabilitas, tidak terjadi multikolinearitas, karena tingkat suku bunga lebih besar dari 0,10. Nilai VIF yang diperoleh untuk variabel rasio kas, working capital turnover, solvabilitas, tingkat suku bunga lebih kecil 10. dapat ditetapkan tidak terjadi multikolinearitas antar variabel independen dalam model regresi tersebut.

\subsubsection{Uji Autokorelasi}

a. Sebelum Transformasi

Tabel 4.7 : Hasil Uji Autokorelasi Sebelum Transformasi

\begin{tabular}{|c|c|c|c|c|c|}
\hline \multicolumn{6}{|c|}{ Model Summary ${ }^{\mathbf{b}}$} \\
\hline odel & $\mathrm{R}$ & $\begin{array}{c}\mathrm{R} \\
\text { Square }\end{array}$ & $\begin{array}{l}\text { Adjusted R } \\
\text { Square }\end{array}$ & $\begin{array}{l}\text { Std. Error of } \\
\text { the Estimate }\end{array}$ & Durbin-Watson \\
\hline 1 &, $318^{\mathrm{a}}$ & ,101 & ,009 &, 06160 & 2,127 \\
\hline
\end{tabular}

a. Predictors: (Constant), BIRATE, DAR, CR, PMK

b. Dependent Variable: ROA

Dari tabel 4.7 diatas menunjukkan bahwa nilai DW yang diperoleh adalah sebesar 2,127. Cara pengukuran uji autokorelasi adalah $\mathrm{du}<\mathrm{dw}<4-\mathrm{du}$. Nilai dl dan du dalam penelitian ini dengan menggunakan jumlah 4 variabel dan sampel penelitian sebanyak 44 maka nilai $\mathrm{dl}=1.3263$ dan nilai $\mathrm{du}=1.7200$. Hasil pengukurannya adalah $\mathrm{du}<\mathrm{dw}$ $<4$ - du maka $1.7200<2,127<(4-1.7200)$ sehingga $1.7200<2,127<2,280$ sehingga disimpulkan tidak terjadi autokorelasi dalam penelitian ini. 
b. Sesudah Transformasi

\begin{tabular}{|c|c|c|c|c|c|}
\hline \multicolumn{6}{|c|}{$\begin{array}{c}\text { Tabel 4.8 : Hasil Uji Autokorelasi Sesudah Transformasi } \\
\text { Model Summary }\end{array}$} \\
\hline Model & $\mathrm{R}$ & $\begin{array}{c}\mathrm{R} \\
\text { Square }\end{array}$ & $\begin{array}{l}\text { Adjusted R } \\
\text { Square }\end{array}$ & $\begin{array}{l}\text { Std. Error of } \\
\text { the Estimate }\end{array}$ & Durbin-Watson \\
\hline 1 &, $511^{\mathrm{a}}$ & ,261 & ,151 & ,92341 & 2,181 \\
\hline
\end{tabular}

Dari tabel 4.8 diatas menunjukkan bahwa nilai DW yang diperoleh adalah sebesar 2,181. Cara pengukuran uji autokorelasi adalah $\mathrm{du}<\mathrm{dw}<4-\mathrm{du}$. Nilai $\mathrm{dl} d a n \mathrm{du}$ dalam penelitian ini dengan menggunakan seluruh hasil 4 variabel dan sampel penelitian sebanyak 32 maka nilai $\mathrm{dl}=1.1769$ dan nilai $\mathrm{du}=1.7323$. Hasil pengukurannya adalah $\mathrm{du}<\mathrm{dw}<4-$ du maka $1.7323<2,181<(4-1.7323)$ sehingga $1.7323<2,181<2,2677$ dapat ditetapkan tidak terjadi autokorelasi dalam penelitian ini.

\subsubsection{Uji Heteroskedastisitas}

a. Sebelum Transformasi

\section{Gambar 4.9 : Scatterplot Sebelum Transformasi}

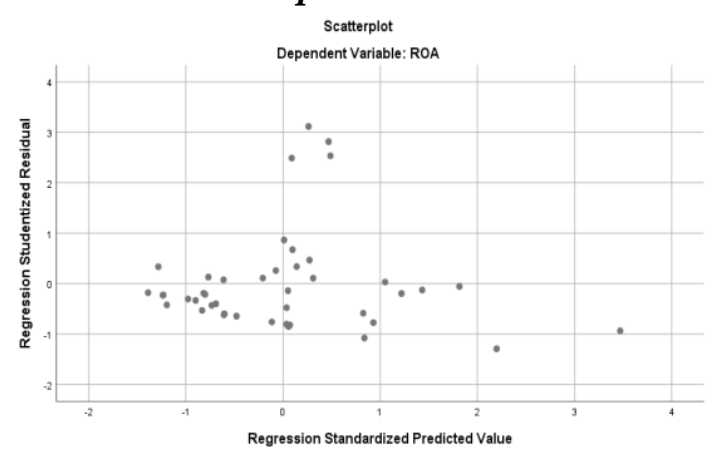

Gambar 4.9 menunjukkan bahwa data tersebar secara tidak acak dan membentuk suatu pola tertentu sehingga menunjukkan terjadi heteroskedastisitas.

b. Sesudah Transformasi

\section{Gambar 4.10 : Scatterplot Sesudah Transformasi}

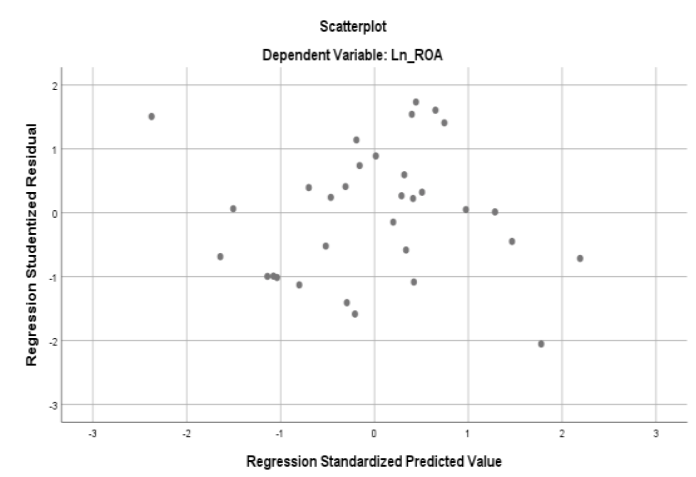


Gambar 4.10 menunjukkan bahwa data tersebar secara acak dan tidak membentuk suatu pola tertentu.Data tersebar diatas garis 0 yang menunjukkan tidak terjadi heteroskedastisitas.

Uji glejser bertujuan untuk meregres nilai absolute residual terhadap variabel independen. Sedangkan untuk uji statistik dapat dilakukan dengan uji Glejser pada tabel 4.11 berikut ini:

Tabel 4.11: Hasil Uji Glejser Sebelum Transformasi

\section{Coefficients ${ }^{\text {a }}$}

\begin{tabular}{|c|c|c|c|c|c|c|}
\hline & \multirow[b]{2}{*}{ Model } & \multicolumn{2}{|c|}{$\begin{array}{l}\text { Unstandardized } \\
\text { Coefficients }\end{array}$} & \multirow{2}{*}{$\begin{array}{c}\text { Standardized } \\
\text { Coefficients } \\
\text { Beta }\end{array}$} & \multirow[b]{2}{*}{$\mathrm{t}$} & \multirow[b]{2}{*}{ Sig. } \\
\hline & & B & Std. Error & & & \\
\hline \multirow[t]{5}{*}{1} & (Constant) &, 096 &, 043 & & 2,245 &, 030 \\
\hline & $\mathrm{CR}$ &,- 018 & ,026 &,- 108 &,- 701 & ,488 \\
\hline & PMK &, 000 & ,001 &,- 049 &,- 280 & ,781 \\
\hline & DAR &,- 103 & 050 &,- 361 & $-2,066$ & ,046 \\
\hline & BIRATE &,- 001 & 005 &,- 021 &,- 142 & 888 \\
\hline
\end{tabular}

a. Dependent Variable: Abs_ut

\section{Sumber : Hasil Pengolahan Data, 2019}

Tabel 4.11 di atas menunjukkan nilai signifikan variabel rasio kas, working capital turnover, tingkat suku bunga di atas 0,05 disimpulkan tidak terjadi heteroskedastisitas. Solvabilitas dengan nilai signifikan di bawah 0,05 disimpulkan terjadi heteroskedastisitas.

\section{Tabel 4.8 : Hasil Uji Glejser Sesudah Transformasi}

\section{Coefficients $^{\mathrm{a}}$}

\begin{tabular}{|c|c|c|c|c|c|c|}
\hline \multirow{2}{*}{\multicolumn{2}{|c|}{ Model }} & \multicolumn{2}{|c|}{$\begin{array}{l}\text { Unstandardized } \\
\text { Coefficients }\end{array}$} & \multirow{2}{*}{$\begin{array}{c}\text { Standardized } \\
\text { Coefficients } \\
\text { Beta } \\
\end{array}$} & \multirow[t]{2}{*}{$\mathrm{t}$} & \multirow[t]{2}{*}{ Sig. } \\
\hline & & $\mathrm{B}$ & Std. Error & & & \\
\hline 1 & (Constant) & ,756 & ,908 & &, 832 & ,413 \\
\hline & Ln_CR &,- 162 &, 116 &,- 363 & $-1,398$ &, 173 \\
\hline & Ln_PMK &,- 128 & ,158 &,- 200 &,- 810 & , 425 \\
\hline & Ln_DAR &,- 184 & ,269 &,- 156 &,- 684 &, 500 \\
\hline & Ln_BIRATE &,- 141 & 442 &,- 061 &,- 319 & ,752 \\
\hline
\end{tabular}

a. Dependent Variable: Abs_ut1

Tabel 4.8 di atas menunjukkan nilai signifikan variabel rasio kas, working capital turnover, solvabilitas, tingkat suku bunga berada di atas 0,05 sehingga disimpulkan terjadi tidak heteroskedastisitas. 


\subsection{ModelPenelitian}

Tabel 4.9 : Hasil Analisis Regresi Linear Berganda

\section{Coefficients $^{\mathrm{a}}$}

\begin{tabular}{|c|c|c|c|c|c|c|}
\hline & \multirow[b]{2}{*}{ Model } & \multicolumn{2}{|c|}{$\begin{array}{l}\text { Unstandardized } \\
\text { Coefficients }\end{array}$} & \multirow{2}{*}{$\begin{array}{c}\text { Standardized } \\
\text { Coefficients } \\
\text { Beta } \\
\end{array}$} & \multirow[b]{2}{*}{$\mathrm{t}$} & \multirow[b]{2}{*}{ Sig. } \\
\hline & & $\mathrm{B}$ & Std. Error & & & \\
\hline \multirow[t]{5}{*}{1} & (Constant) & $-3,305$ & 1,698 & & $-1,947$ &, 062 \\
\hline & Ln_CR & ,191 &, 217 & ,205 &, 884 & ,385 \\
\hline & Ln_PMK &,- 286 & 295 &,- 213 &,- 970 & 341 \\
\hline & Ln_DAR &,- 501 &, 503 &,- 202 &,- 996 & ,328 \\
\hline & Ln_BIRATE & ,306 &, 826 &, 063 & ,371 & ,714 \\
\hline
\end{tabular}

a. Dependent Variable: Ln_ROA

Berdasarkan tabel IV.10 di atas diperoleh rumus regresi sebagai berikut:

Ln_ROA $=-3,305+0,191$ Ln_CR - 0,286 Ln_PMK - 0,501 Ln_DAR + 0,306 Ln_BI

Hasil interpretasi dari regresi tersebut adalah sebagai berikut:

1. Nilai a sebesar $-3,305$ artinya jika variabel rasio kas, working capital turnover, solvabilitas, tingkat suku bunga dianggap konstan, maka profitabilitas adalah sebesar $-3,305$.

2. Nilai koefisien rasio kas $\left(\mathrm{X}_{1}\right)$ adalah 0,191 . Ini menunjukkan bahwa setiap peningkatanrasio kas satu kali maka profitabilitas akan mengalami peningkatan sebesar 0,191.

3. Nilai koefisien working capital turnover $\left(\mathrm{X}_{2}\right)$ sebesar -0,286. Ini menunjukkan bahwa setiap penurunan working capital turnover satu kali maka profitabilitas akan mengalami penurunan sebesar 0,286.

4. Nilai koefisien solvabilitas $\left(\mathrm{X}_{3}\right)$ sebesar $-0,501$. Ini menunjukkan bahwa setiap penurunan solvabilitas satu kali maka profitabilitas akan mengalami penurunan sebesar 0,501 .

5. Nilai koefisien tingkat suku bunga bi rate $\left(\mathrm{X}_{4}\right)$ sebesar 0,306 . Ini menunjukkan bahwa setiap kenaikan tingkat suku bunga bi rate satu kali maka profitabilitas akan mengalami peningkatan sebesar 0,306.

\subsubsection{Koefisien Determinasi $\left(\mathbf{R}^{2}\right)$}

Uji koefisien determinasi digunakan untuk mengetahui seberapa besar tingkat pengaruh variabel bebas dapat menjelaskan variabel terikat. Semakin tinggi nilai koefisien determinasi, maka semakin baik pengaruh varian dan variabel bebas menerangkan variabel terikat:

\section{Tabel 4.10 : Koefisien Determinasi}

$$
\text { Model Summary }{ }^{b}
$$

\begin{tabular}{lc|r|r|r} 
Model & $\mathrm{R}$ & R Square & $\begin{array}{c}\text { Adjusted } \\
\text { R Square }\end{array}$ & $\begin{array}{c}\text { Std. Error of } \\
\text { the Estimate }\end{array}$ \\
\hline 1 &, $511^{\mathrm{a}}$ &, 261 &, 151 &, 92341 \\
\hline
\end{tabular}

a. Predictors: (Constant), Ln_BIRATE, Ln_DAR, Ln_PMK, Ln_CR

b. Dependent Variable: Ln_ROA 
Berdasarkan tabel 4.10 di atas diperoleh nilai adjusted $R$ Square $\left(\mathrm{R}^{2}\right)$ koefisien determinasi sebesar 0,151 atau sama dengan $15,1 \%$ dipengaruhi oleh variabel independen terhadap variabel dependen sedangkan sisanya $84,9 \%$ dipengaruhi variabel lain seperti seperti, perputaran kas, perputaran aktiva, dan struktur modal.

\subsubsection{Pengujian Hipotesis Secara Simultan}

Tabel 4.11 : Hasil Uji Statistik F

ANOVA $^{\mathrm{a}}$

\begin{tabular}{c|r|r|r|r|r} 
Model & Sum of Squares & df & Mean Square & F & Sig. \\
\hline $1 \quad$ Regression & 8,125 & 4 & 2,031 & 2,382 &, $076^{\mathrm{b}}$ \\
\hline Residual & 23,023 & 27 &, 853 & & \\
\hline Total & 31,148 & 31 & & & \\
\hline
\end{tabular}

a. Dependent Variable: Ln_ROA

b. Predictors: (Constant), Ln_BIRATE, Ln_DAR, Ln_PMK, Ln_CR

Dari tabel 4.11 di atas, bisa dilihat hasil $\mathrm{F}_{\text {hitung }}$ adalah sebesar 2,382dengan nilai signifikan 0,076 sedangkan $\mathrm{F}_{\text {tabel }}(32-5=27)$ adalah sebesar 2,73 maka kesimpulannya adalah $F_{\text {hitung }}<\mathrm{F}_{\text {tabel }}$ yaitu 2,382 $<2,73$ sehingga kepastiannya adalah Ho diterima dan Ha ditolak, artinya variabel Rasio kas, working capital turnover, solvabilitas, tingkat suku bunga tidak berpengaruh dan tidak signifikan terhadap profitabilitas (studi empiris pada aneka industri yang terdaftar di Bursa Efek Indonesia Periode2013-2016).

\subsubsection{Pengujian Hipotesis Secara Parsial}

Tabel IV.12 : Hasil Uji Statistik t

\section{Coefficients ${ }^{\mathrm{a}}$}

\begin{tabular}{|c|c|c|c|c|c|}
\hline \multirow[b]{2}{*}{ Model } & \multicolumn{2}{|c|}{$\begin{array}{l}\text { Unstandardized } \\
\text { Coefficients }\end{array}$} & \multirow{2}{*}{$\begin{array}{c}\text { Standardized } \\
\text { Coefficients } \\
\text { Beta }\end{array}$} & \multirow[t]{2}{*}{$\mathrm{T}$} & \multirow[t]{2}{*}{ Sig. } \\
\hline & $\mathrm{B}$ & Std. Error & & & \\
\hline (Constant) & $-3,305$ & 1,698 & & $-1,947$ &, 062 \\
\hline Ln_CR & ,191 &, 217 & ,205 &, 884 & ,385 \\
\hline Ln_PMK &,- 286 & 295 &,- 213 &,- 970 & ,341 \\
\hline Ln_DAR &,- 501 & ,503 &,- 202 &,- 996 & ,328 \\
\hline Ln_BIRATE & ,306 & ,826 &, 063 & ,371 & ,714 \\
\hline
\end{tabular}

a. Dependent Variable: Ln_ROA

Hasil pengujian statistik secara parsial sebagai berikut:

1. Tabel IV.12 di atas menunjukkan variabel Rasio kas mempunyai nilai $t_{\text {hitung }}$ adalah sebesar 0,884 dengan nilai signifikan 0,385>0,05, sedangkan nilai $t_{\text {tabel }}$ $(32-4=28)$ adalah sebesar 2,048 sehingga keputusannya yaitu $t_{h i t u n g}<t_{\text {tabel }}$ yaitu $0,884<2,048$ maka keputusannya yaitu Ho diterima dan $\mathrm{H}_{\mathrm{a}}$ ditolak, artinya variabel Rasio kas tidak berpengaruh dan tidak signifikan terhadap profitabilitas (studi empiris pada aneka industri yang terdaftar di Bursa Efek Indonesia Periode2013-2016). 
2. Variabel working capital turnovermempunyai nilai $t_{\text {hitung }}-0,970$ dengan nilai signifikan 0,341>0,05, sedangkan $t_{\text {tabel }}$ yaitu sebesar 2,048 maka kesimpulannya adalah $-\mathrm{t}_{\text {hitung }}>-\mathrm{t}_{\text {tabel }}$ yaitu $-0,970>-2,048$ sehingga keputusannya yaitu Ho diterima dan $\mathrm{H}_{\mathrm{a}}$ ditolak, artinya variabel Working capital turnover tidak berpengaruh negatif dan tidak signifikan terhadap profitabilitas (studi empiris pada aneka industri yang terdaftar di Bursa Efek Indonesia Periode2013-2016).

3. Variabel solvabilitas mempunyai nilai thitung-0,996 dengan nilai signifikan $0,328>0,05$, sedangkan $t_{\text {tabel }}$ yaitu sebesar 2,048 maka keputusannya yaitu - $t_{\text {hitung }}$ $>$-t tabel yaitu -0,996>-2,048 sehingga keputusannya yaitu Ho diterima dan $\mathrm{H}_{\mathrm{a}}$ ditolak, artinya variabel Solvabilitas tidak berpengaruh dan tidak signifikan terhadap profitabilitas (studi empiris pada aneka industri yang terdaftar di Bursa Efek Indonesia Periode2013-2016).

4. Variabel tingkat suku bunga mempunyai nilai $t_{\text {hitung }} 0,371$ dengan nilai signifikan $0,714>0,05$, sedangkan $t_{\text {tabel }}$ adalah sebesar 2,048 maka kesimpulannya adalah $\mathrm{t}_{\text {hitung }}<\mathrm{t}_{\text {tabel }}$ yaitu $0,371<2,048$ sehingga keputusannya adalah Ho diterima dan $\mathrm{H}_{\mathrm{a}}$ ditolak, artinya variabel Tingkat suku bunga tidak berpengaruh positif dan tidak signifikan terhadap profitabilitas (studi empiris pada aneka industri yang terdaftar di Bursa Efek Indonesia Periode2013-2016).

\subsection{Pembahasan}

\subsubsection{Pengaruh Rasio Kas Terhadap Profitabilitas}

Rasio kas tidak berpengaruh dan tidak signifikan terhadap profitabilitas (studi empiris pada aneka industri yang terdaftar di Bursa Efek Indonesia Periode2013-2016).

Karena jika perusahaan berada dalam keadaan kurang baik, ada kemungkinan perusahaan tidak bisa memanfaatkan kesempatan potongan (pembelian tunai) yang diberikan oleh para leveransiernya. Sebagai mengakibatkan perusahaan terpaksa beroperasi pada tingkat modal yang tinggi, sehingga mengurangi kesempatan untuk meraih laba yang lebih besar.

Hasil penelitian ini tidak sejalan dengan penelitian yang dilakukan Putri dan Triaryati (2017) yang menyatakan, Rasio kas (Cash Ratio) berpengaruh negatif signifikan terhadap profitabilitas aset.

\subsubsection{Pengaruh Working Capital Turnover Terhadap Profitabilitas}

Working capital turnover tidak berpengaruh dan tidak signifikan pada profitabilitas (studi empiris pada aneka industri yang terdaftar di Bursa Efek Indonesia Periode 2013-2016).

karena, perputaran modal kerja yang tinggi mungkin disebabkan karena tingginya perputaran persediaan barang dagang atau piutang usaha, atau bisa juga karena terlalu kecilnya saldo kas sebaliknya, terlalu besarnya saldo atau bisa juga kas Karena rendahnya perputaran persediaan barang dagang atau piutang usaha.

Hasil penelitian ini sama halnya dengan penelitian yang dilakukan Nugroho (2013) yang menyatakan, tidak terdapat pengaruh secara signifikan efisiensi modal kerja terhadap profitabilitas studi kasus pada PT. Telekomunikasi Indonesia, Tbk. 


\subsubsection{Pengaruh Solvabilitas Terhadap Profitabilitas}

Solvabilitas tidak berpengaruh dan tidak signifikan terhadap profitabilitas (studi empiris pada aneka industri yang terdaftar di Bursa Efek Indonesia Periode 2013-2016).

karena jika suatu perusahaan mampu memenuhi kewajiban finansialnya pada saat perusahaan tersebut dilikuidasi dapat dikatakan kondisi tingkat kinerja keuangan perusahaan dalam keadaan sehat. Faktor-faktor lain yang mempengaruhi tingkat kinerja keuangan perusahaan yang juga mencerminkan tingkat efisiensi perusahaan adalah aktivitas. Aktivitas merupakan alat untuk mengukur sampai seberapa besar efektivitas perusahaan dalam menggunakan sumber-sumber dananya untuk menghasilkan pendapatan.

Hasil penelitian ini sama halnya dengan penelitian yang dilakukan Nugroho (2013) yang menyatakan, Tidak terdapat pengaruh secara signifikan solvabilitas terhadap profitabilitas studi kasus pada PT. Telekomunikasi Indonesia, Tbk

\subsubsection{Pengaruh Tingkat Suku Bunga Terhadap Profitabilitas}

Tingkat suku bunga tidak berpengaruh dan tidak signifikan terhadap profitabilitas (studi empiris pada aneka industri yang terdaftar di Bursa Efek Indonesia Periode 2013-2016).

Hasil penelitian ini tidak sama hanya dengan penelitian yang dilakukan Kalengkongan (2013) yang menyatakan, Tingkat suku bunga berpengaruh signifikan dan positif terhadap profitabilitas.

\section{KESIMPULAN DAN SARAN}

\subsection{Kesimpulan}

Berdasarkan hasil penelitian di atas maka dapat ditarik beberapa kesimpulan sebagai berikut:

1. Rasio kas tidak berdampak positif dan tidak signifikan terhadap profitabilitas (Studi empiris pada aneka industri yang terdaftar di Bursa Efek Indonesia Periode 2013-2016).

2. Working capital turnover tidak berdampak negatif dan tidak signifikan pada profitabilitas (studi empiris pada aneka industri yang terdaftar di Bursa Efek Indonesia Periode 2013-2016).

3. Solvabilitas tidak berdampak negatif dan tidak signifikan pada profitabilitas (studi empiris pada aneka industri yang terdaftar di Bursa Efek Indonesia Periode 20132016).

4. Tingkat suku bunga tidak berdampak dan tidak signifikan pada profitabilitas (studi empiris pada aneka industri yang terdaftar di Bursa Efek Indonesia Periode 2013-2016).

5. Rasio kas, working capital turnover, solvabilitas, tingkat suku bunga tidak berdampak dan tidak signifikan pada profitabilitas (studi empiris pada aneka industri yang terdaftar di Bursa Efek Indonesia Periode 2013-2016).

\subsection{Saran}

Berdasarkan hasil penelitian di atas ini maka peneliti memberikan beberapasaran sebagai berikut:

1. Bagi Pihak Manajemen Aneka Industri, sebaiknya memperhatikan faktor lain yang mempengaruhi profitabilitas dinilai tingkat laba bersih perusahaan tidak mengalami 
peningkatan mungkin disebabkan adanya pembayaran hutang jangka yang tinggi walaupun rasio kas yang tersedia tinggi, adanya perputaran modal kerja yang lambat, tingginya tingkat hutang dan rendahnya suku bunga.

2. Bagi peneliti selanjutnya, sebaiknya mengganti variabel independen lain yang mempengaruhi profitabilitas, memperpanjang masa pengamatan dan mengganti perusahaan sektor lain.

3. Bagi Universitas Prima Indonesia, sebaiknya hasil penelitian ini dapat berguna bagi Mahasiswa-Mahasiswi lain yang tertarik untuk meneliti faktor yang mempengaruhi profitabilitas.

\section{DAFTAR PUSTAKA}

Ghozali, Imam.2016. Aplikasi Analisis Multivariate Dengan Program IBM SPSS.Jakarta : Penerbit Universitas Diponegoro

Gumanti, Tatang Ary. 2011. Manajemen Investasi. Jakarta : Penerbit Mitra Wacana Media

Harahap, Sofyan Sayfri, 2013. Analisis Kritis Atas Laporan Keuangan Keuangan. Jakarta : Penerbit PT Rajagrafindo Persada

Hery. 2016. Financial Ratio For Business Analisis Keuangan Untuk Menilai Kondisi Finansial dan Kinerja Perusahaan. Jakarta : Penerbit PT Gramedia

Kalengkongan. 2013. Tingkat Suku Bunga dan Inflasi Pengaruhnya Terhadap Return on Asset (ROA) Pada Industri Perbankan yang Go Public di Bursa Efek Indonesia, Jurnal Emba, Manado.

Kamaludin dan Indriani. 2012. Manajemen Keuangan. Penerbit CV. Mandar Maju. Bandung,

Kasmir. 2012. Analisis Laporan Keuangan. Cetakan Kelima.Jakarta : Penerbit Rajagrafindo Persada

Kasmir. 2014. Analisis Laporan Keuangan. Cetakan Kelima.Jakarta : Penerbit Rajagrafindo Persada.

Nugroho. 2013. Analisis Pengaruh Efisiensi Modal Kerja, Likuiditas dan Solvabilitas Terhadap Profitabilitas Atudi Kasus Pada PT. Telekomunikasi Indonesia, Tbk.

Putri dan Triaryati. 2017. Pengaruh Likuiditas (Cash Ratio) dan Loan to Deposit Ratio Terhadap Profitabilitas Aset (ROA) Pada Sektor Perbankan yang Tercatat di Bursa Efek Indonesia Periode 2008-2012.

Sanusi, Anwar. 2012. Metodologi Penelitian Bisnis. Jakarta : Penerbit Salemba Empat. Sitanggang, J.P. 2012. Manajemen Keuangan Perusahaan. Jakarta : Penerbit Mitra Wacana Media

Sunyoto, Danang. 2013. Dasar-dasar Manajemen Keuangan Perusahaan. Yogyakarta : Penerbit Caps.

Wahyudiono. 2014. Mudah Membaca Laporan Keuangan. Jakarta Timur : Perum Bukit Permai. 